\title{
Erratum to: Biology and host specificity of Rhinusa pilosa, a recommended biological control agent of Linaria vulgaris
}

\author{
André Gassmann · Rosemarie De Clerck-Floate • \\ Sharlene Sing • Ivo Toševski • Milana Mitrović • \\ Oliver Krstić
}

Published online: 23 May 2014

(C) International Organization for Biological Control (IOBC) 2014

\section{Erratum to: BioControl \\ DOI 10.1007/s10526-014-9578-7}

The first name of the last author was incorrectly spelled in the original publication. It shows correctly in this erratum.

The online version of the original article can be found under doi:10.1007/s10526-014-9578-7.

\footnotetext{
A. Gassmann $(\bowtie) \cdot$ I. Toševski

CABI, Rue des Grillons 1, 2800 Delémont,

Switzerland

e-mail: a.gassmann@cabi.org

I. Toševski

e-mail: tosevski_ivo@yahoo.com

R. De Clerck-Floate

Agriculture and Agri-Food Canada, Lethbridge Research Centre, 5403 1st Avenue South, Lethbridge, AB T1J 4B1, Canada

e-mail: rosemarie.declerck-floate @agr.gc.ca
}

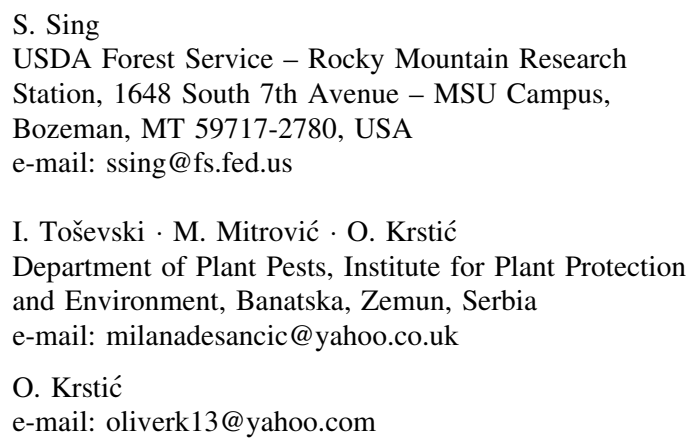

